\title{
EDITORIAL
}

\section{Writing in Response}

In this special double issue, $C V 2$ hosts a dialogue among a selection of writers who have been influenced by French feminist theorists, and who in turn, are beginning to have an impact on the way we think about language and women's writing. Granted, much of this impact is controversial for us at $C V 2$, as past issues will testify. It's also true that the debate, "Is Feminist Theory Anti-Feminist," which Valerie Raoul so deftly handles at the end of this issue is still ongoing here - sometimes between our readers and ourselves, often between ourselves, and more often between the voices in our own heads. Jan Horner's pseudo-equations in her editorial of 10,4 underscore some intense exchanges on the subject, and at the same time, offer us a new way of looking at the nature of controversy itself:

$$
\begin{aligned}
\text { contemporary } \times \text { contemporary } & =\mathrm{CV} 2 \\
\text { contemporary versus contemporary } & =\text { controversies } \\
\text { version vs. version } & =\mathrm{CV} 2 \\
\text { subversion vs. subversion } & =\mathrm{CV} 2
\end{aligned}
$$

\section{contralversions}

I think it's more wholistic to look at controversy as the sum total of all possible contralversions rather than to focus on the two polarities which arbitrarily frame them. In other words, to tackle the theory vs. activism debate head-on radically constricts the possibility for dialogue. We fall into a binary trap and can't talk to one another. And so it would seem that one of the most subversive (and difficult!) things we can do as feminists is to remain in controversy. In theory, at any rate, the CV 2 and Tessera collectives meet in a network of contralversions; versions which speak out against the enormous patriarchal investment in language to shape the world in an exclusively masculine image.

If we listen closely to the voices in this issue, what we hear is not so much a rejection of social activism, but anxiety and disillusionment with its potential to effect positive change in our lives. Distancing herself, at least initially, from any emotional agenda, Barbara 
Godard surveys the landscape of feminist utopian fiction and notes the shift from the optimistic novels of the '70's to the pessimistic or cautionary tales of the ' 80 's. Without totally discounting the validity of a political interpretation, Godard actually sees positive potential in the shift "away from the prescriptive role of liberal and radical feminist theory." Quite frankly, I don't understand how this shift would make room for "establishing 'woman' as a position within discourse" or why such a position would be desirable. And yet I can see this problem at the centre of the American feminist movement over the past twenty years. Too many women were excluded from the prescription for an essentially white, educated, middle-class constituency. However, the challenge to feminist theories presented by marginalized women continues to result in a widening and deepening of feminist analysis and practise in the United States.

Another problem with prescriptive "policy" which Godard and others in this issue are particularly concerned about is that it can lead to effects that are unintended and unexpected. No-fault divorce legislation is a good example in which we find the principle of "equality" turned on us like a weapon. Writers in this issue point to how the electronic media have translated and manipulated earlier gains of feminist activism into a portrait of the "post-feminist" woman. We don't know her personally, but she's everywhere - in commercials, in Chatelaine, on the cover of Macleans, and she has it "all." She, too, is a weapon; a symbol of economic and social privilege. As I study her picture on the cover of a November issue of Macleans, I am heartened by Barbara Godard's remark that as feminists we must also "transform the ways in which we perceive the world and the methods by which we arrive at this new knowledge."

Any differences we may have over how theory and activism can work together are diminished by the widening consensus among feminists that "feminism" means nothing short of changing the world. And if we would change the world, we must perceive it differently than we do now.

To change the way we think is one of the most exciting and treacherous projects we can undertake. The exciting part is in the implicit affirmation of these new theories that emancipation from patriarchal constraints in our language, our writing and our lives is possible. The treacherous part lies in working out methods to arrive 
at this new knowledge. It means disengaging ourselves from what Sonia Johnson calls the "complicity" of upholding old patterns which have excluded, misrepresented or degraded women (and still do.) This is a difficult and painful process, and I think probably the biggest challenge to feminist theorists writing in Canada, Quebec and elsewhere.

In post-structuralist theory, language becomes the exclusive focus for any investigation into how we perceive the world. "It is widely accepted that reality cannot be apprehended directly but is mediated through language," writes Susan Knutson in "Challenging the Masculine Generic." Well, even if some of us don't subscribe to this $100 \%$, it is important to recognize just how much the words we use shape our thoughts and perceptions. In her fascinating study, Knutson examines a whole minefield of words in common usage which betray patriarchal bias and privilege. Against this backdrop, those "petty" skirmishes many of us have had over words like chairman don't appear petty at all. And much to Susan Knutson's credit, it doesn't take a quantum leap to see how feminist analysis and practise are related to each other in this article.

It is difficult to credit a number of other articles in this issue with similar breadth. My concern is not so much that they are too intellectual or too theoretical, but rather that the highly specialized language they use precludes the possibility for dialogue among a wide base of feminist readers. And that is unfortunate. How is it that writers like Louise Dupre are concerned that the feminist movement has been taken over by various levels of government and yet no one in this issue expresses a similar concern about being co-opted by the academy? It won't be apparent to many readers, for example, that Julia Emberley's "The Pain of the Text - Anger: Intertextuality: Gender" is an academic parody. It might be because we haven't read the "right" books, but it might also be because anger is too close to the bone of felt experience for the parody to work. Perhaps the real pain of the text has yet to find an authentic language to speak through.

"Higher learning" is crucial to any advances we make in changing the ways we think. Still, we have a right to be skeptical of the impact of contemporary theories on our universities, which after all, continue to flourish on hierarchy and privileged discourse. It's no small irony that people who denounce such hierarchy and privilege 
in theory actually get tenure these days. We need to scrutinize our academic associations very carefully, for unless feminist research is grounded in the overall network of feminist dialogue and practise, we will see courses in post-feminist theory popping up 15 to 20 years from now.

For CV 2, endless exchanges on ideological differences or degrees of political involvement are integral to the feminist process. We do have a problem, however, when the prevailing discourse in an important field of feminist enquiry excludes many more readers than it includes. So it's encouraging to hear a hint of redress in Tessera's call for papers for issue 6: "academic discourse is discouraged."

Jane Casey 